\title{
An Analysis of the Use of Smartphone in Students' Interaction at Senior High School
}

\author{
Deni Sutisna* \\ Primary School Education Study \\ Program \\ Universitas Mataram \\ Mataram, Indonesia \\ denisutisna@unram.ac.id \\ Umar Umar \\ Primary School Education Study \\ Program \\ Universitas Mataram \\ Mataram, Indonesia
}

\author{
Arif Widodo \\ Primary School Education Study \\ Program \\ Universitas Mataram \\ Mataram, Indonesia
}

\author{
Muhammad Sobri \\ Primary School Education Study \\ Program \\ Universitas Mataram \\ Mataram, Indonesia
}

\author{
Nursaptini Nursaptini \\ Primary School Education Study \\ Program \\ Universitas Mataram \\ Mataram, Indonesia
}

\author{
Dyah Indraswati \\ Primary School Education Study \\ Program \\ Universitas Mataram \\ Mataram, Indonesia
}

\begin{abstract}
This study aims to analyze the use of smartphones towards students' interaction at senior high school. This descriptive qualitative research was carried out at one of the senior high schools in Pangalengan, Bandung with observation and interview techniques. It shows that smartphones can change the interaction pattern in associative and dissociative processes. In the associative proses, students create social media groups to communicate, interact, and socialize in order to make it easier for students to distribute information. Meanwhile, the dissociative process occur friction due to misunderstanding in interpreting information when communicating. Another finding in this research shows that the use of smartphones can facilitate teachers and students in the learning process and evaluation. However, the impact on the use of smartphone is that the students lack focus in the teaching and learning process. Smartphones are used as a means of cheating, bullying and shifting values and norms.
\end{abstract}

Keywords - smartphone, social interaction, associative process, dissociative process

\section{INTRODUCTION}

Technology is a humans' effort to facilitate way and performance. In the times development, technology continues to develop in a more modern direction. In the era of modernization and digitalization nowadays, technological developments especially communication continues to increase. Indonesia is a country with a high use of technology. It is natural in order to follow the world's development by following the trend of technology in communication. A country will become fall behind if the people do not want to follow technology and if the government limits the use of technology development [1].

The development of technology in communication especially smartphones is increasingly modern from time to time. Smartphone is a communication tool that developed from a mobile phone which has more modern and complete features [2]. In the beginning, smartphones were only used by interested people such as employees, students, and adults who use it to support profession [3], yet smartphone was not restricted from age and profession nowadays.

Among teens, especially students, smartphone becomes a necessity. Smartphone does not only serve as a communication tools, but it also can provide satisfaction through the applications in it. Its development has changed the lifestyle of its users. Basically, the purpose of using a smartphone is to facilitate people in communication. Smartphone can be a very useful media in establishing relationships, connections and searching for information [4]. The right smartphone usage strategy can be a fun medium of learning for students who can provide great progress for the world of education [5].

In the world of education especially among students, there are a lot problems caused by smartphones particularly when used in a school environment. Instead of facilitating on learning process, the excessive use of smartphone can give impact on the student interaction pattern. As stated by [6] that smartphones have a great influence on students' social interaction patterns. Further, research of [7] states that smartphones can change the social interaction processes, and [8] say that smartphones caused laziness and difficulty for students in interacting directly so there are bondage tendency on smartphones.

Based on the above problems, we examine the problems that might occur at one of the high schools in Pangalengan. From the preliminary study, it is suspected that there was a change pattern of students' interaction that caused by smartphone usage. This research was done at one of the high schools in the Pangalengan due on preliminary observations that showed the school is a school that utilizes the sophistication of smartphones in the field of teacher attendance and in carrying out online-based learning and evaluation so that students are free to use smartphones in the school environment. In this case, the school has not yet applied standard rules related to the use of smartphone at schools.

This study aims to examine the problems that may arise from the use of smartphones at schools. The main problem 
that becomes the research topic is how are the interaction patterns of students who use a smartphone in school. Through this research, it is expected to find practical solutions in overcoming problems or negative impacts arising from smartphone use in schools.

\section{METHOD}

This research applied descriptive qualitative method. It is intended to make an actual and systematic description, painting of the facts, nature, and relationships of the phenomenon under the study [9]. Data were collected with observation and interviews with 8 students and 3 teachers using the interview guide instrument. The rest of the data were obtained by observing during the study. Analysis was done by analyzing, presenting and summarizing the data [10].

\section{FINDINGS AND DISCUSSION}

The research location is one of the schools that utilize smartphones in the teacher's attendance and in the implementation of student learning and evaluation. In addition, the school does not have rules that prohibit the use of smartphones at school environment. Based on the results of interviews with teachers, there are several factors why the school provides freedom on the use of smartphones at schools; 1). Schools are located in rural areas, limited access to the public transportation, the majority of students use motorbikes, students were picked by their parents, and many students live far from school locations, therefore smartphones make an easier communication between students and parents; 2). Smartphones are expected to become learning media in terms of finding references, doing assignments, looking for information, and looking for subject matter; 3) as a learning evaluation tool. In this case, smartphone is used as a means of online learning, especially in terms of evaluations such as daily tests, middle semester and end semester tests. Another factor is due to the students' desire to bring smartphones as means for existence and actualization.

Smartphones have functions to facilitate the process of communication, socialization and interaction. Nevertheless, the results of the interview stated that not all students can understand that smartphone is used to interact instead the existence of smartphones can make difficulty for some people to interact and socialize. Moreover, many students become less sensitive to their environments since they prefer to play smartphones rather than playing or discussing. This can reduce social intelligence since social intelligence must be built from the presence of social skills. Social skills were developed and obtained from the students' frequency in interacting directly or face to face. Meanwhile when using gadgets, the directly interaction elements will be reduced [11].

Basically, with smartphone or not, students still interact with each other. But, the interaction patterns nowadays are far different from the ancient times. Students stated that "If we have problem in finding information about a person, we can just find them through social media then we can easily find information about that person". This implies that most students are believed to have social media accounts such as face book, line, instagram, and WhatsApp or others. Even though, students who do not bring smartphones to school will borrow a friend's smartphone. Interaction on social media is different from interactions in the real world. Hence, social media provides a new form of interaction that brings users back to interpersonal relationships and individuals can interact with each other in real time [12].

Theoretically, social interaction recognizes two forms which are the associative and dissociative process [13]. Both of these interaction processes will continue occur to humans regardless of the conditions. Related to this, smartphones have a big role in changing the process of social interaction. The associative process focuses on the process of cooperation and accommodation. A form of student cooperation that can be facilitated by smartphones is creating social media groups such as WA, Facebook and Messenger, where WA is the dominant application used by students. The groups that students make are diverse, ranging from class groups, extracurricular groups, games groups, hobby groups, work assignment groups, and others. It aims to facilitate the information so that the information distributed is right on target. This is in accordance with what was said by [14] that WA can change the social life, and culture of the community.

Initially, social media groups can be used as a media of group discussion. One of the students says "In the past, discussion really had to be face-to-face, but now students can discuss wherever members of the group are located without having face-to-face. Meeting in person is needed if the results of the discussion cannot be resolved in the group". This is strengthened with the statement stating that smartphone can affect students' social skills [15].

As discussed earlier, social media groups, especially WA were created to facilitate the distribution of information both information from friends and teachers. However, for students who are less responsible, it becomes a gap to take actions that are slightly deviant. An interview with one of the teacher states that "During the exam, students take photos of the questions then share them with the other classes. Even worse, not only the questions, but the answer keys were also shared to the other classes regardless of the correct or wrong answer key. Although sometimes there are different test questions for each class but still they will know the limits or scope of the material that will be the test material, so that it can harm the other classes ". This was done in groups, so that the assessment is less effective.

Next, dissociative process emphasizes more on competition and convention. At school, there are sometimes misunderstandings due to social media. As one student said that "When we discuss or chat in groups or personally in WA, we cannot see the expressions of people talking (except using video) so that sometimes there are misinterpretations that caused offense". Other cases happens when someone shares a status that is not infrequently offends others or self-image in a group such as showing off possessions, sharing photos of foods, and shopping that sometimes causes competition or friction among students. This is in accordance with [16] who stated that smartphones have changed the way of communicating and interacting. This is sometimes one of the factors 
causing disputes between students in high schools especially in Pangalengan area.

When conducting research, the researcher found that there were other findings related to the impact of smartphone use in schools. The results of interviews with students and teachers revealed that the use of smartphones has positive and negative impacts. The positive impact is that smartphones are used as a means of communication, information-seeking tools, learning media, assessment media, and self-development media.

Different reality happened at SMAN 1 Pangalengan. There were only few students who were able to use smartphones, especially for learning. Most students used smartphones at school just to satisfy their enjoyment. These findings confirm that although smartphones have many benefits and is used for education, the excessive use of smartphone in the school environment, especially among students, can give negative impact. This is in line with the research results from [17] which revealed that the positive or negative effects of the technology depend on the users.

Other findings showed that students are more interested in smartphones than learning. In addition, the concentration in learning reduced, smartphones are used as a means of cheating, finding pornographic content, spreading hoax news, bullying, and shifting in values, norms, and habits. Moreover, the negative effects of smartphones can cause addiction, so that students do not have enough control in using a smartphone since its concentration is interrupted by the applications in it [18]

Smartphone is actually able to be an effective medium for learning. There are several benefits that can be found in the learning process. For teachers, smartphone will make them more easily to process and analyze the difficulties of students in implementing and evaluating the online learning so that they will save time, money and energy. For students, smartphone will able to facilitate the learning process. Hence, its uses will depend on the individual itself. For creative students, smartphone can provide space to develop themselves and interests. Many features direct students to become more active so they can develop their hobbies and potential. This is in accordance with the statement from [19] that Smartphones with internet connections have the benefits to speed up work, add connections, business facilities, media promotion, and selfdevelopment media. Finally, the use of smartphones among students can be an effective and efficient way of finding information, forming self-confidence, increasing knowledge, and giving access to learning material that can be accessed everywhere in anytime [20].

\section{CONCLUSION}

Based on the analysis, it can be concluded that smartphones can change the patterns of students' social interaction at school. In the associative process, students create social media groups to communicate, interact, and socialize in order to make an easier way for students in distributing information. On the other hand, the dissociative process leads to friction and dispute due to the misunderstanding in interpreting some information when communicating.

Thus, it shows that smartphones have both negative and positive effects. The positive effects for teachers can be seen in the teaching and learning process, in which it can help teachers in the process of learning, assessments and evaluation that were done online and this will save time, energy, and costs. For students, smartphones can be used as a learning media in finding and processing information. Whereas, the negative effects of smartphone can cause lack concentration of students in studying. In addition, the smartphone is also used as a medium for cheating, finding content of pornography, hoax news dissemination, bullying, shifting values, norms, and also habits.

\section{REFERENCES}

[1] N. Heri, Sejarah Perkembangan Tekhnologi [The history of technology development]. Jakarta Timur: PT Budi Pstaka Persero, 2012.

[2] N. Hasanah dan D. Kumalasari, "Penggunaan Handphone dan Hubungan Teman Pada Prilaku Sosial Siswa SMP Muhammadiyah Luwuk Sulawesi," Harmon. Sos., vol. 151, no. 1, page. 10-17, 2015.

[3] Y. Warisyah, "Prosiding Seminar Nasional 'Pendidikan Pentingnya Pendampingan Dialogis Orang Tua Dalam Penggunaan Gadget Pada Anak Usia Dini,”" 2015, no. Inovasi Pembelajaran Untuk Pendidikan Berkelanjutan, page. 1.

[4] B. Manumpil, A. Ismanto, dan F. Onibala, "Hubungan Penggunaan Gadget Dengan Tingkat Prestasi Siswa Di Sma Negeri 9 Manado," J. Keperawatan UNSRAT, vol. 3, no. 2, page. $1-6,2015$

[5] Rachmadi dan G. Aldiano, Easy Parenting Strategy:Menumbuhkan Minat Baca Sejak Usia Dini. Bandung: Adwrite Publishing, 2019.

[6] D. Supriatno dan I. Romadhon, "Pengaruh Media Komunikasi Smartphone Terhadap Interaksi Sosial Pelajar (Studi Deskriptif Kuantitatif pada Pelajar SMK Astra Nawa Ambulu)," Paradig. Madani, vol. 4, no. 2, page. 65-74, 2017.

[7] A. Efendi, P. I. Astuti, dan N. T. Rahayu, "Analisis Pengaruh Penggunaan Media Baru Terhadap Pola Interaksi Sosial Anak Di Kabupaten Sukoharjo," J. Penelit. Hum., vol. 18, no. 2, page. 12, 2017.

[8] A. Marsal dan F. Hidayati, "Pengaruh Smartphone Terhadap Pola Interaksi Sosial Pada Anak Balita Di Lingkungan Keluarga Pegawai Uin Sultan Syarif Kasim Riau," J. Ilm. Rekayasa dan Manaj. Sist. Inf., vol. 3, no. 1, page. 78-84, 2017.

[9] M. Nazir, Metode Penelitian [Research methods]. Bogor: Ghallia Indonesia, 2005

[10] Sugiono, Metode Penelitian Pendidikan (Pendekatan Kuantitatif, Kualitatif, dan R\&D). Bandung: Alfabeta, 2013.

[11] D. Harfiyanto, C. B. Utomo, dan T. Budi, "Pola Interaksi Sosial Siswa Pengguna Gadget Di SMAN 1 Semarang," JESS (Journal Educ. Soc. Stud., vol. 4, no. 1, page. 1-5, 2015.

[12] F. Gunawan, F. Abdul Muis, dan Syamsudin, Reloigion Study dan Media Sosial. Yogyakarta: CV Budi Utama, 2018.

[13] S. Soekanto, Soiologi Suatu Pengantar [Sociology: An introduction], 46 ed. Jakarta: PT Rajagrafindo Persada, 2014

[14] N. Kumar dan S. Sharma, "Survey Analysis on the usage and Impact of Whatsapp Messenger," Glob. J. Enterp. Inf. Syst., 2017.

[15] T. Dewanti, W. Widada, dan T. Triyono, "Hubungan Antara Keterampilan Sosial Dan Penggunaan Gadget Smartphone Terhadap Prestasi Belajar Siswa Sma Negeri 9 Malang," J. Kaji. Bimbing. dan Konseling, vol. 1, no. 3, hal. 126-131, 2016.

[16] M. Adila Mat Saruji, N. Hafizah Hassan, dan S. Md.Drus, "Impact Of ITC and Electronic Gadget Among Young Children In Education: a Conseptual Model," in Proceedings of the 6th International Conference on Computing and Informatics, ICOCI 2017, 2017, vol. 10, no. 4, hal. 1458-1461. 
[17] N. Khairuni, "Dampak Positif dan Negatif Sosial Media Terhadap Pendidikan Akhlak Anak (Studi Kasus di SMP Negeri 2 Kelas VIII Banda Aceh)," J. EDUKASI J. Bimbing. Konseling, vol. 2, no. 1, hal. 91-106, 2016.

[18] J. Lee, B. Cho, Y. Kim, dan J. Noh, "Smartphone addiction in university students and its implication for learning," Lect. Notes Educ. Technol., 2015.
[19] A. Noelka, Isu-Isu Kritis Pendidikan (Utama, Namun Tetap Penting, Namun Tetap Terabaikan). Jakarta: Prenada Media Grup, 2018.

[20] S. O'Connor dan T. Andrews, "Smartphones and mobile applications (apps) in clinical nursing education: A student perspective," Nurse Educ. Today, vol. 69, hal. 72-78, 2018. 